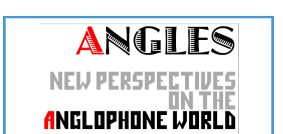

ANELOPHONE WORLI

\section{Angles}

New Perspectives on the Anglophone World

$10 \mid 2020$

Creating the Enemy

\title{
Graphic Interlude: Creating the Enemy
}

\section{Theodor Seuss Geisel, Rick Smolan and David Cohen}

\section{(2) OpenEdition}

\section{Journals}

\section{Electronic version}

URL: http://journals.openedition.org/angles/422

DOI: 10.4000/angles.422

ISSN: 2274-2042

\section{Publisher}

Société des Anglicistes de l'Enseignement Supérieur

\section{Electronic reference}

Theodor Seuss Geisel, Rick Smolan and David Cohen, « Graphic Interlude: Creating the Enemy », Angles [Online], 10 | 2020, Online since 01 April 2020, connection on 15 September 2020. URL : http:// journals.openedition.org/angles/422

This text was automatically generated on 15 September 2020 .

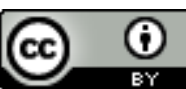

Angles est mise à disposition selon les termes de la Licence Creative Commons Attribution 4.0 International. 


\section{Graphic Interlude: Creating the}

\section{Enemy}

Theodor Seuss Geisel, Rick Smolan and David Cohen

AUTHOR'S NOTE

With Anonymous artist 
Figure 1. George Cruickshank, The Radical's Arms (1819)

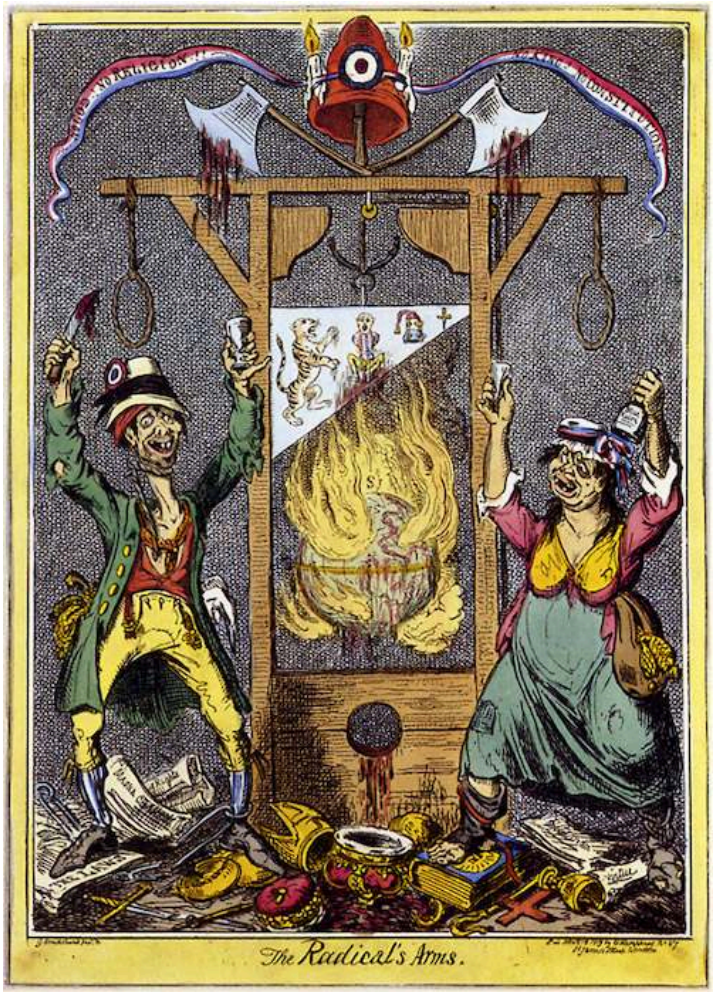

Source: https://www.brh.org.uk/site/articles/guillotine-knitting-terror

1 The Radical's Arms by English caricaturist George Cruickshank is a good example of British counter-revolutionary propaganda stereotyping the French after 1789, with the guillotine a symbol of terror and anarchy.

Figure 2. Sir John Tenniel, A Lesson (1879)

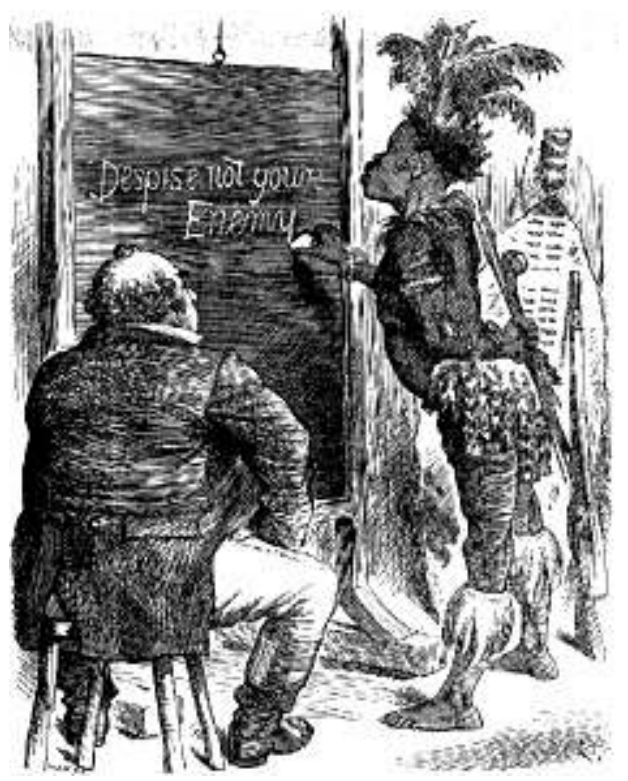

Source: http://projects.vassar.edu/punch/hires1.html 
2 Sir John Tenniel's “A Lesson" (1879), published in Punch, may be subverting the enemy image. While the Zulu warrior appears as primitive and uncivilized as can be expected for the time, that he schools an Englishman, by writing in English no less, suggests "savages" should not be underestimated.

Figure 3. Dr. Seuss, What have you done today to help save your country from them? 1942

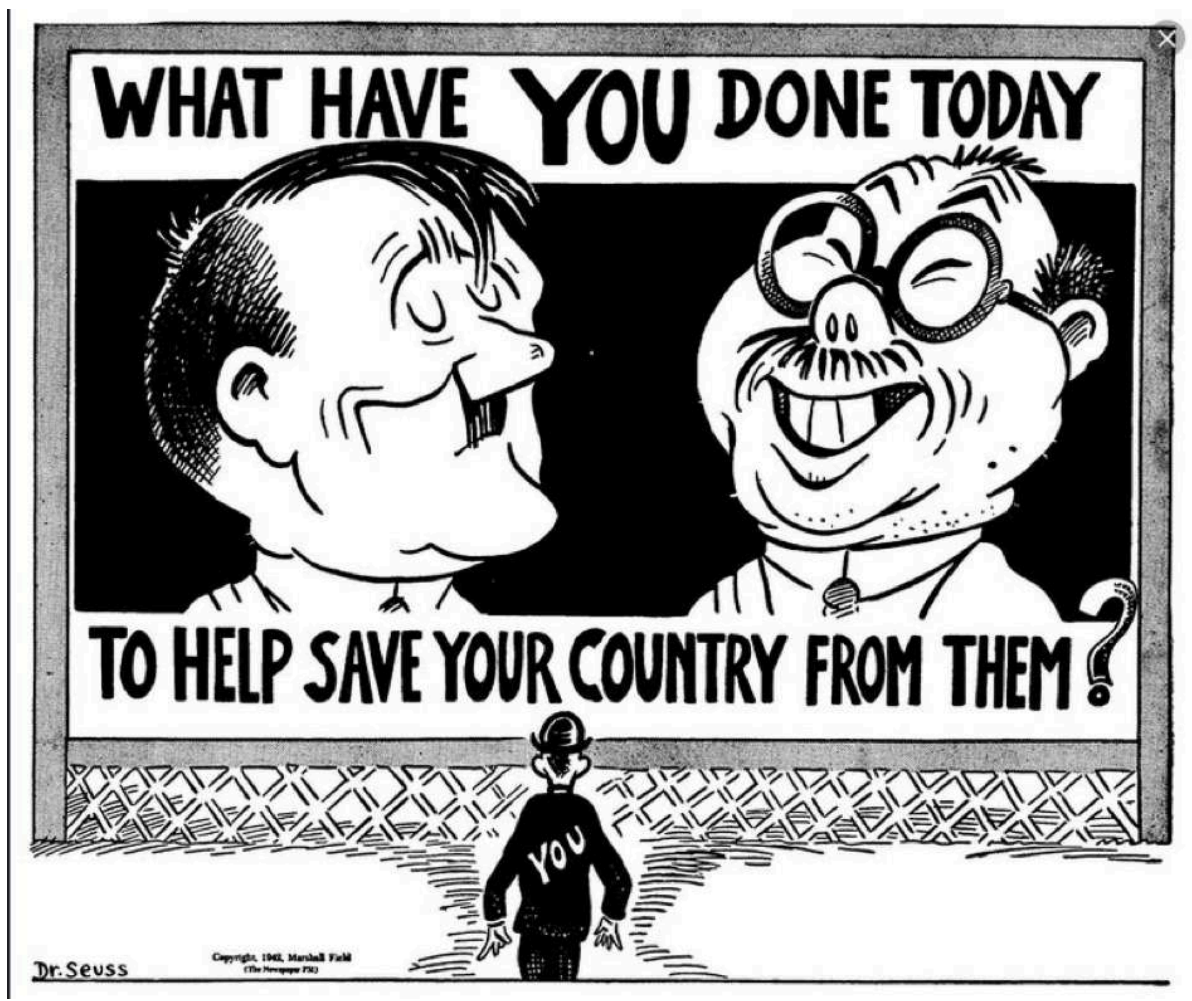

Source: http://library.ucsd.edu/dc/object/bb12977599

3 Children's author Theodor Seuss “Ted" Geisel, better known as Dr Seuss, worked as an editorial cartoonist for the paper PM from 1941 to 1943. His work reflects a fundamental difference in American propaganda during World War II: Hitler and Nazism were the enemy rather than the German people whereas the Japanese as a whole were very much portrayed through racist tropes. 
Figure 4. Cover of Time magazine, 26 October 1987, Vol. 130, No. 17.

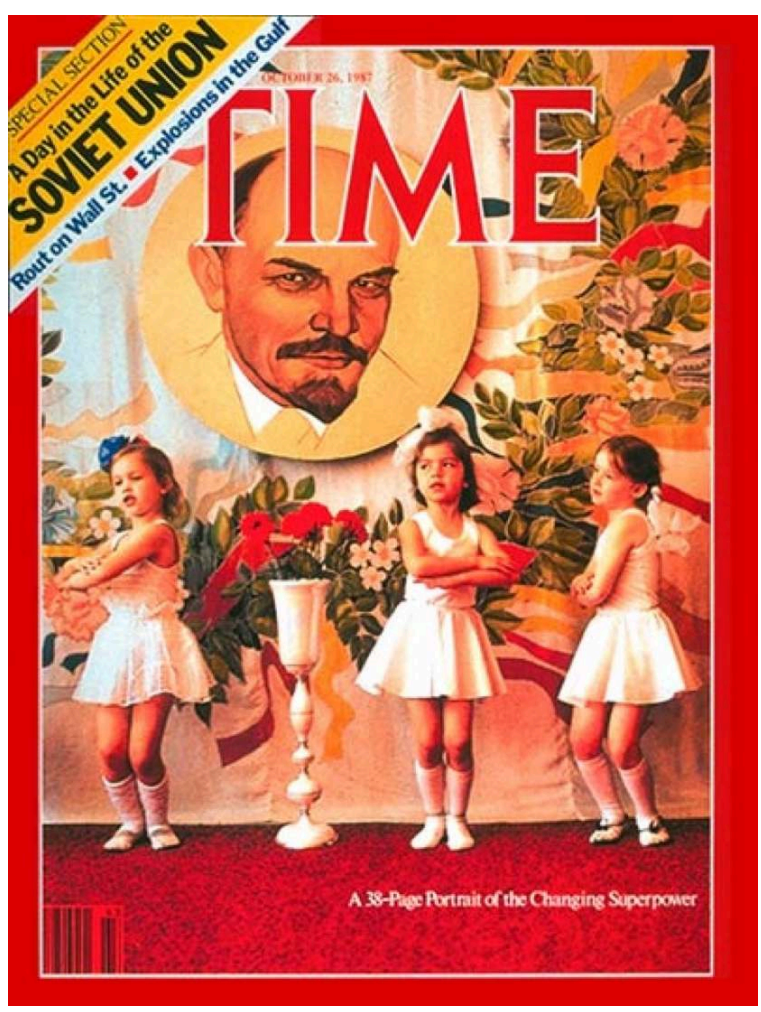

Source: http://content.time.com/time/magazine/0,9263,7601871026,00.html

4 In October 1987, Time published a series of photographs collected by journalist Rick Smolan and editor David Cohen. Despite Lenin's portrait being somewhat reminiscent of Big Brother's in 1984, this cover really subverts the enemy image of the Soviets during the Cold War. Instead of soldiers, the Soviets are represented by three little girls in white dresses, a symbol of innocence and purity. The photograph suggests that the enemy isn't the Soviet people, but the Soviet system; such a distinction heralds the end of the Cold War. 
Figure 5. Sinchon Massacre, Sinchon Museum of American War Atrocities, North Korea

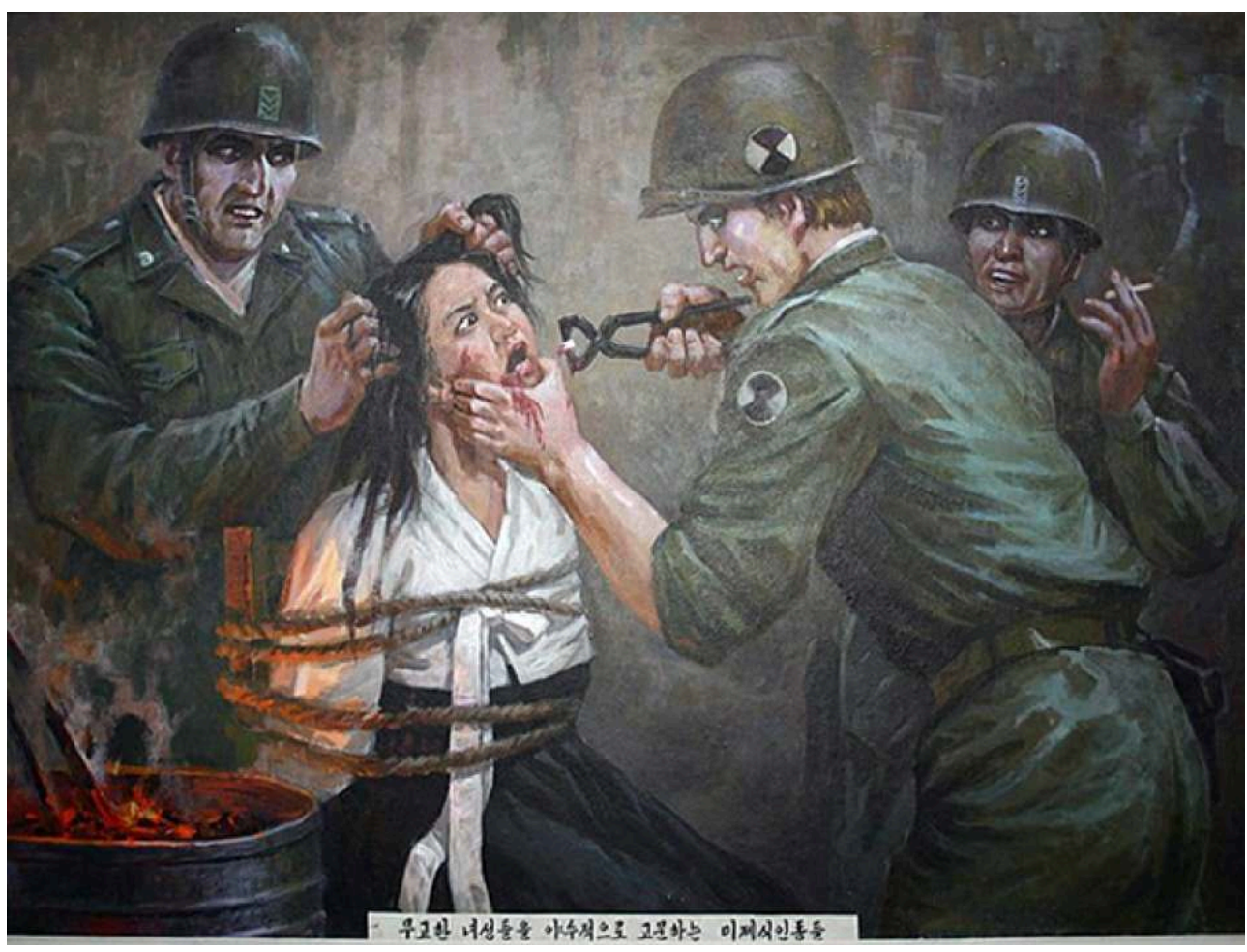

Source: https://en.wikipedia.org/wiki/Sinchon_Museum_of_American_War_Atrocities

5 The Sinchon Museum of American War Atrocities in North Korea presents numerous exhibits seeking to expose the barbarity of American soldiers during the Korean War. This painting is a particularly good example of the male enemy brutalizing a powerless female.

Figure 6. Real threats

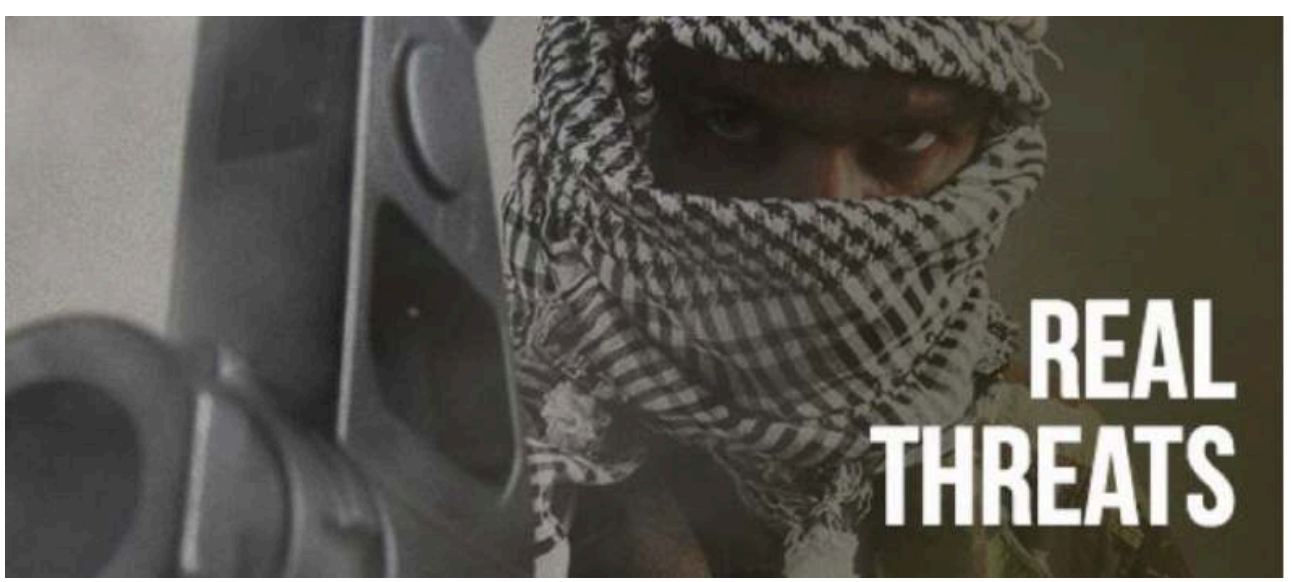

6 From the far-right website Breitbart, the section "real threats" uses a stereotypical image of the Muslim terrorist. Breitbart regularly mocks Islam as a fake "religion of peace" to convey the idea that all Muslims are dangerous for Western civilization. 


\section{ABSTRACTS}

This graphic interlude features pictures illustrating this issue's topic: creating the enemy.

Cet interlude graphique est composé d'images qui illustrent le thème de ce numéro: la mer comme symbole, métaphore et unité d'analyse.

INDEX

Mots-clés: ennemi, image ennemie, guerre

Keywords: enemy, enemy image, war 